\title{
Bochdalek hernia with volvulus and invasive candida complication
}

\section{Volvulus ve invaziv kandida komplikasyonuyla Bochdalek hernisi birlikteliği}

\author{
Esra KARAKUŞ ${ }^{1}$, Müjdem Nur AZILI ${ }^{2}$, Gülşah BAYRAM ${ }^{3}$, Bahar ÇUHACI ÇAKIR ${ }^{4}$, Emrah ŞENEL ${ }^{2}$ \\ ${ }^{1}$ Ankara Çocuk Sağlı̆̆ı ve Hastalıkları Hematoloji ve Onkoloji Eğitim Araştırma Hastanesi, Patoloji Bölümü, Ankara, Türkiye \\ ${ }^{2}$ Ankara Çocuk Să̆lı̆̆ı ve Hastalıkları Hematoloji ve Onkoloji Eğitim Araştırma Hastanesi, Çocuk Cerrahisi Bölümü, Ankara, Türkiye \\ ${ }^{3}$ Ankara Çocuk Sağlığ ve Hastalıkları Hematoloji ve Onkoloji Eğitim Araştırma Hastanesi, Radyoloji Bölümü, Ankara, Türkiye \\ ${ }^{4}$ Ankara Çocuk Sağlığı ve Hastalıkları Hematoloji ve Onkoloji Ĕ̆itim Araştırma Hastanesi, Pediatri Bölümü, Ankara, Türkiye
}

A 1-year old girl was incidentally diagnosed as left posterolateral diaphragmatic hernia. Imaging methods like X-ray of the chest showed the herniation of gut loops and spleen (Figure 1). In the laparotomy, transverse colon, ascending colon and spleen were seen to enter the left throracic cavity and the organs were taken into the abdominal cavity. During

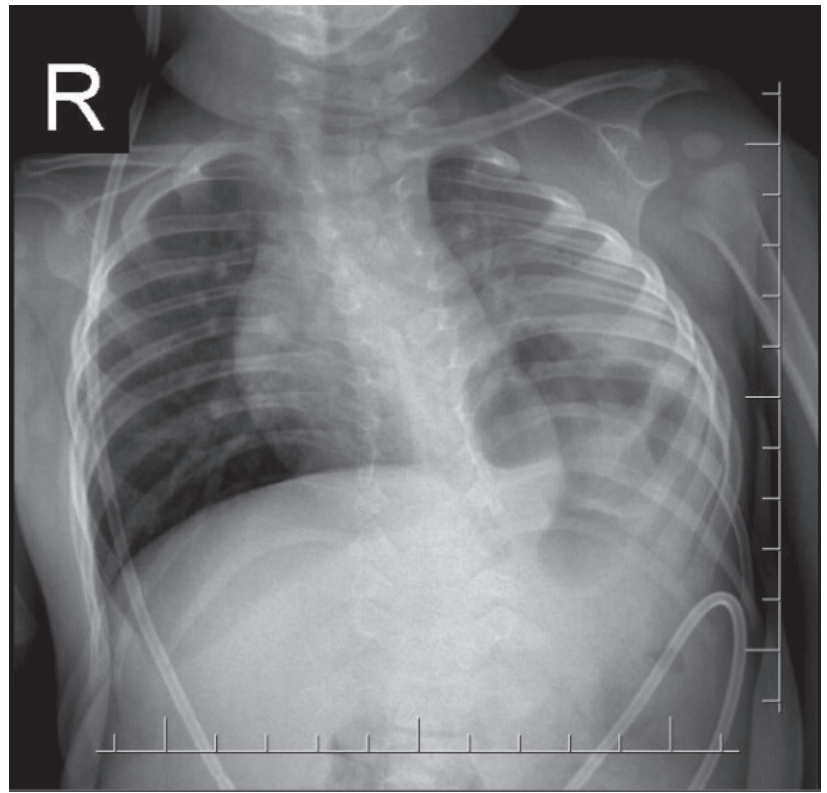

Figure 1. X-ray of the chest showed herniation of gut loops and spleen. the postoperative period, Candida albicans was cultured from urine and cathether-drawn blood cultures. On the postoperative fourth day, abdominal distension and intestinal obstruction occured. An emergency surgery was performed and necrosis of small bowels and ascending and transverse colon due to midgut volvulus were observed related with malrotation. Primary resection and anastomosis were performed for the gangrenous volvulus segment. Macroscopic examination of the intestinal segment revealed dark red to purple to black and thickened intestinal wall (Figure 2A). Microscopic examination of the resec-

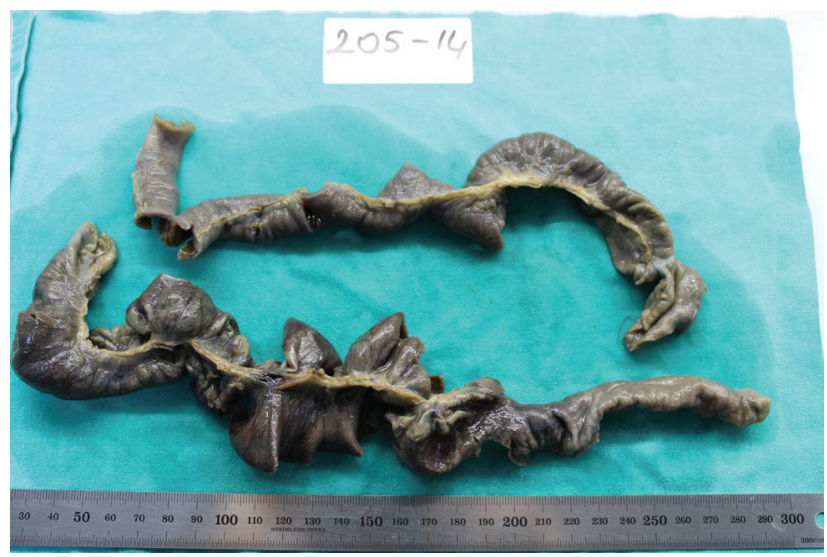

Figure 2A. Macroscopic examination of the intestinal segment was dark red to purple to black and intestinal wall was found to be thickened.

Alındığı tarih: 18.01.2018

Kabul tarihi: 19.03 .2018

Yazışma adresi: Uzm. Dr. Esra Karakuş, Ankara Çocuk Sağlığı ve Hastalıkları Hematoloji Onkoloji Eğitim ve Araştırma Hastanesi Patoloji Kliniği, Ankara - Türkiye

e-mail: esrakaraku@gmail.com 

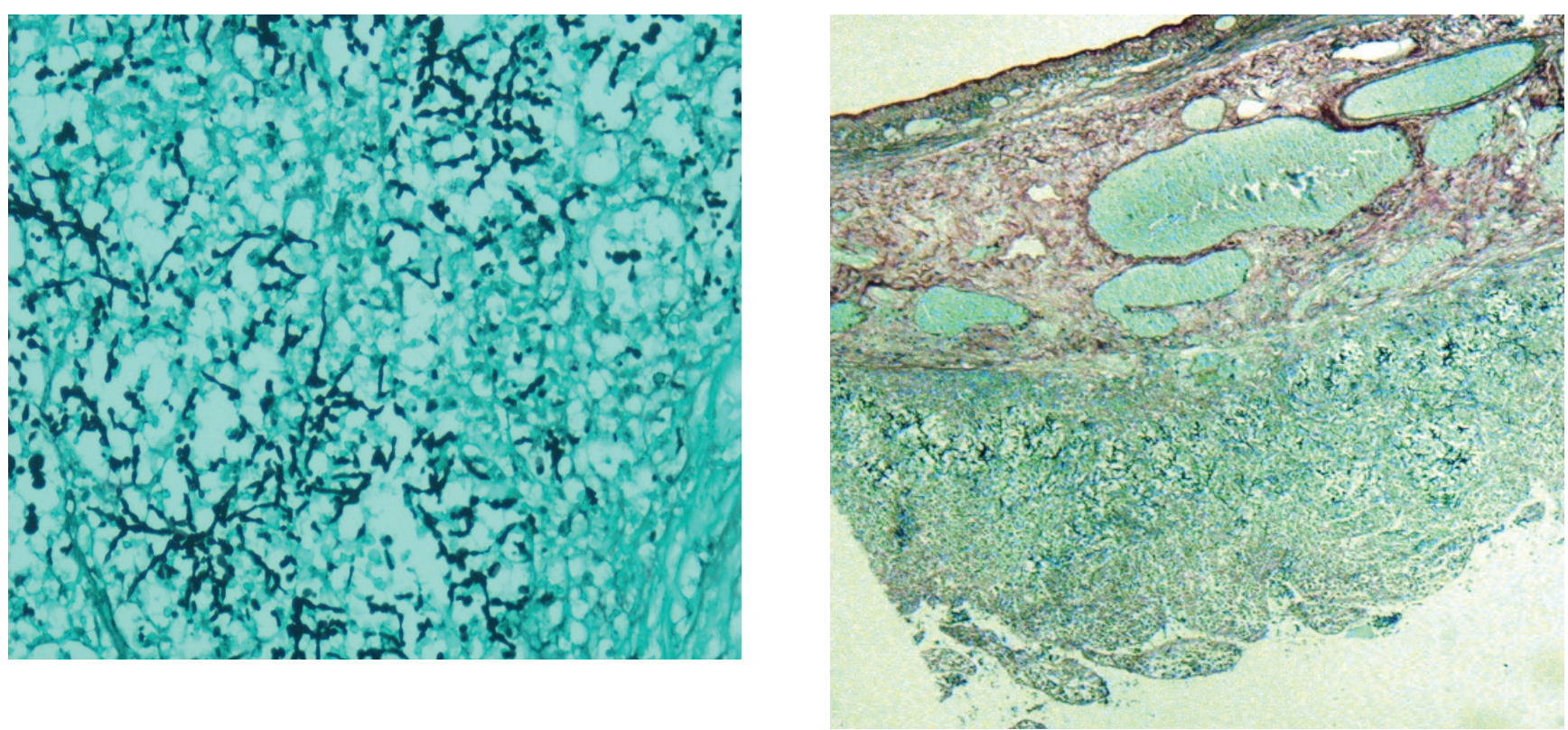

Figure 2B-2C. Grocott-Gomori methenamine-silver (GMS) stain highlighting fungal elements.

ted specimen disclosed congestion, edema, mucosal necrosis, and mild to severe perivascular inflamation. Invasive candida infection embedded in the mucosa was also observed. Presence of fungi was demonstrated by immunohistochemical staining with GrocottGomori methenamine-silver (GMS) and periodic acid-Schiff (PAS) (Figure 2B-2C).

We describe a case of diaphragmatic eventration with colon volvulus and accompanying invasive candida infection. Although Bochdalek hernia eventration complicated by colon volvulus has been reported in the literature, there is not any report documenting hernia eventration complicated by colon volvulus accompanied by invasive candida infection ${ }^{(1,2)}$.

\section{REFERENCES}

1. Ayala JA, Naik-Mathuria B, Olutoye OO. Delayed presentation of congenital diaphragmatic hernia manifesting as combined-type acute gastric volvulus: a case report and review of the literature. J Pediatr Surg. 2008;43:e35-9. https://doi.org/10.1016/j.jpedsurg.2007.11.015

2. Kocakusak A, Arikan S, Senturk O, Yucel AF. Bochdalek's hernia in an adult with colon necrosis. Hernia. 2005;9:284-7. https://doi.org/10.1007/s10029-004-0302-x 